\title{
Airway Epithelium Plays a Leading Role in the Complex Framework Underlying Respiratory Allergy
}

\author{
López-Rodríguez JC'1 Benedé $\mathrm{S}^{1}$, Barderas R ${ }^{1,2}$, Villalba $\mathrm{M}^{1}$, Batanero $\mathrm{E}^{1}$
}

\author{
'Departamento de Bioquímica y Biología Molecular I, Facultad de Ciencias Químicas, Universidad Complutense, \\ Madrid, Spain \\ ${ }^{2}$ UFIEC, National Institute of Health Carlos III, Majadahonda, Spain
}

J Investig Allergol Clin Immunol 2017; Vol. 27(6): 346-355

doi: 10.18176/jiaci.0201

\begin{abstract}
Airway epithelium is the cellular structure with the greatest surface exposed to a plethora of environmental airborne substances, including microorganisms, respiratory viruses, air pollutants, and allergens. In addition to being a protective physical barrier at the air-liquid interface, the airway epithelium acts as an effective chemical and immunological barrier that plays a crucial role in orchestrating the immune response in the lungs, by supporting the activation, recruitment, and mobilization of immune cells. Airway epithelium dysfunction has been clearly associated with various airway inflammatory diseases, such as allergic asthma. Although it is not fully understood why a person develops respiratory allergy, a growing body of evidence shows that the nature of the host's immune response is strongly determined by the state of the airway epithelium at the time of contact with the inhaled allergen. Our review highlights the physiological state of airway epithelium as a key element in the development of allergy and, particularly, in exacerbation of asthma. We review the role of physiological oxidants as signaling molecules in lung biology and allergic diseases and examine how high exposure to air pollutants (eg, cigarette smoke and diesel particles) can contribute to the increased incidence of respiratory allergy and exacerbation of the disease.
\end{abstract}

Key words: Airway epithelium. Barrier dysfunction. Respiratory allergy. Redox biology. Air pollutants.

\section{Resumen}

El epitelio pulmonar constituye la barrera celular más susceptible a la acción deletérea de la multitud de agentes que se encuentran en el ambiente, incluidos los alérgenos. Además de prevenir su acceso al organismo, la barrera epitelial de las vías respiratorias juega un papel inmunomodulador crucial, regulando de forma local la acción de las células del sistema inmune subyacentes. Una disfunción epitelial, provocada tanto directa como indirectamente por la acción de los aeroalérgenos, parece ser una de las causas principales de desregulación de la homeostasis pulmonar, causando una respuesta proinflamatoria descontrolada que cada vez más autores atribuyen al origen de las reacciones alérgicas. En esta revisión se quiere destacar el papel de la barrera epitelial pulmonar como regulador de la respuesta inmune en el contexto de la alergia. Las enfermedades crónicas que afectan a las vías respiratorias, tales como el asma alérgica, muestran frecuentemente una función epitelial defectuosa, apoyando así la hipótesis antes mencionada que subyace al origen de la alergia. El impacto de otros contaminantes ambientales -como virus respiratorios, bacterias, humo del tabaco y partículas diésel- sobre la integridad epitelial, así como su influencia en la biología redox pulmonar relacionada con el desarrollo de la respuesta alérgica, también se abordarán en la presente revisión.

Palabras clave: Epitelio pulmonar. Disfunción epitelial. Alergia respiratoria. Biología redox. Contaminantes ambientales. 


\section{Introduction}

The lung is a complex internal organ that is widely exposed to airborne substances (eg, microorganisms, respiratory viruses, air pollutants, and allergens), which are frequently expelled without inducing lung inflammatory responses because of the crucial role of the airway epithelium in the regulation of immune homeostasis and the development of defense mechanisms.

Over the last few decades, increasing evidence has indicated an association between a dysfunctional epithelium and airway inflammatory diseases [1], of which respiratory allergy is considered a key inflammatory disorder of the conducting airways. Respiratory allergy is characterized by a dominant $\mathrm{CD}^{+} \mathrm{T}$-helper $2\left(\mathrm{~T}_{\mathrm{H}} 2\right)$-type immune response and by the production of high levels of specific IgE against antigens called aeroallergens (Figure 1). Pollen from trees, weeds and grasses, mold spores, house dust mite fecal particles, and animal dander are common sources of aeroallergens. These particles use the upper airways as the main portal of entry into the body, with the airway epithelium being not only the protective physical barrier that they have to overcome, but also an active immunochemical capable of orchestrating allergen-associated immune responses [2]. It is not fully understood why a person develops respiratory allergy, although a growing number of studies suggest that this clinical disorder is the result of a complex interplay between genetics and the environment [3].

Although the debate about whether an impaired airway epithelium can be the cause of allergy - as opposed to the consequence-remains unresolved, a growing body of evidence indicates that the nature of the host immune response is strongly determined by the developmental state of the epithelium at the time of contact with the inhaled allergen [4].

Moreover, several studies have addressed the role of oxidative stress in allergic inflammation (Figure 2) [5]. The lung epithelium is continuously exposed to oxidants generated during normal metabolism or present in the environment (eg, ozone, nitrogen dioxide, car exhaust emissions, and cigarette smoke). Besides the deleterious effects of these molecules, physiologic oxidants have been shown to be signaling molecules and key regulators of allergic responses in the lung $[6,7]$.

Our review focuses on the airway epithelium as the key orchestrator in the complex framework underlying respiratory allergy. We examine the role of the airway epithelium as a key

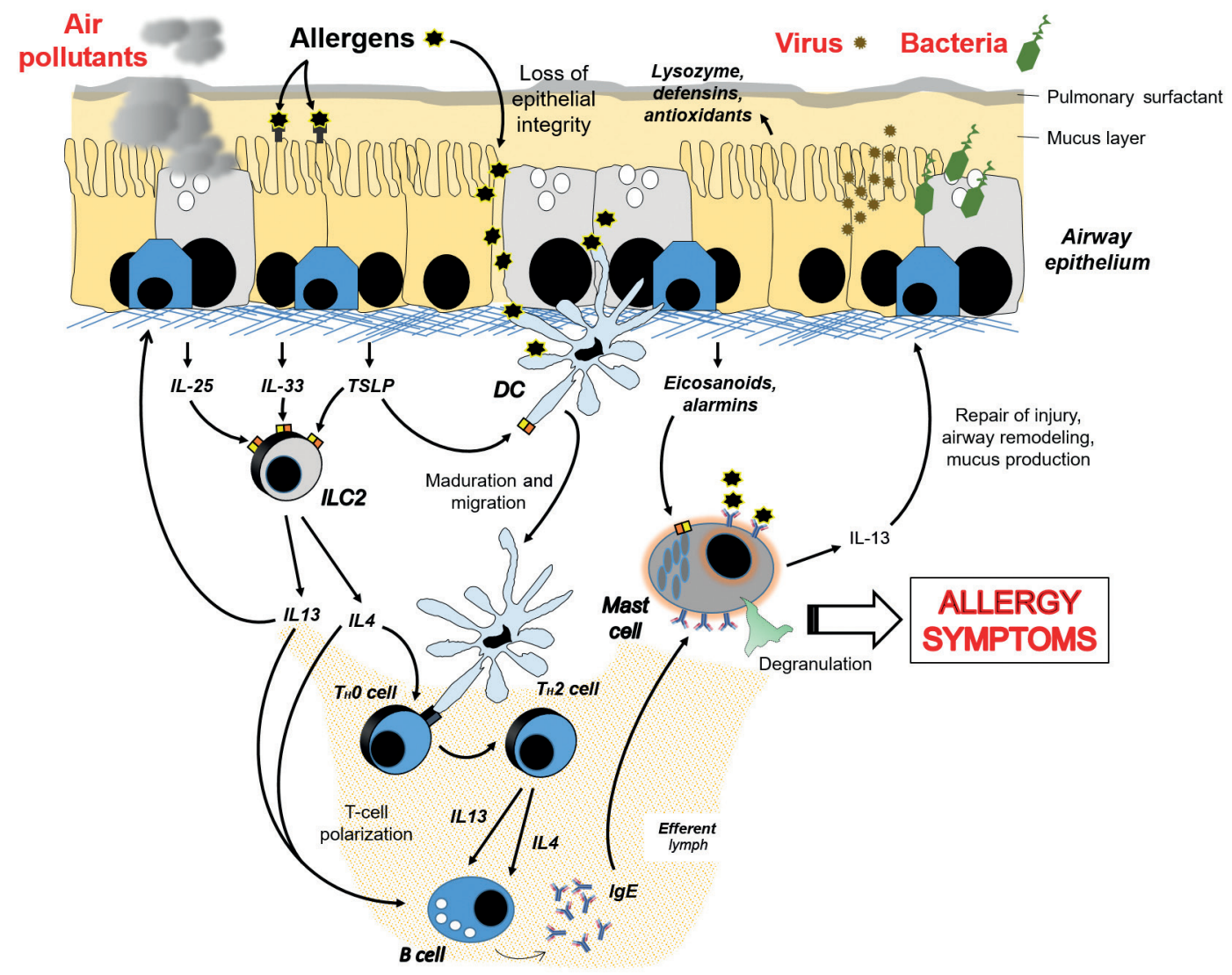

Figure 1. Schematic representation of the role of airway epithelial cells in promoting a $T_{H} 2$-type immune response to aeroallergens. Airway epithelial cells are able to sense inhaled substances (including air pollutants, allergens, viruses, and bacteria) that are constantly threatening epithelial integrity and homeostasis. They can promote the release of a vast set of molecules, including interleukins (IL), chemokines, and inflammatory mediators. This in turn contributes to the characteristic $\mathrm{T}_{\mathrm{H}} 2$-mediated response of allergic reactions through activation of dendritic cells (DC), type-2 innate lymphoid cells (ILC2), and mast cells. 


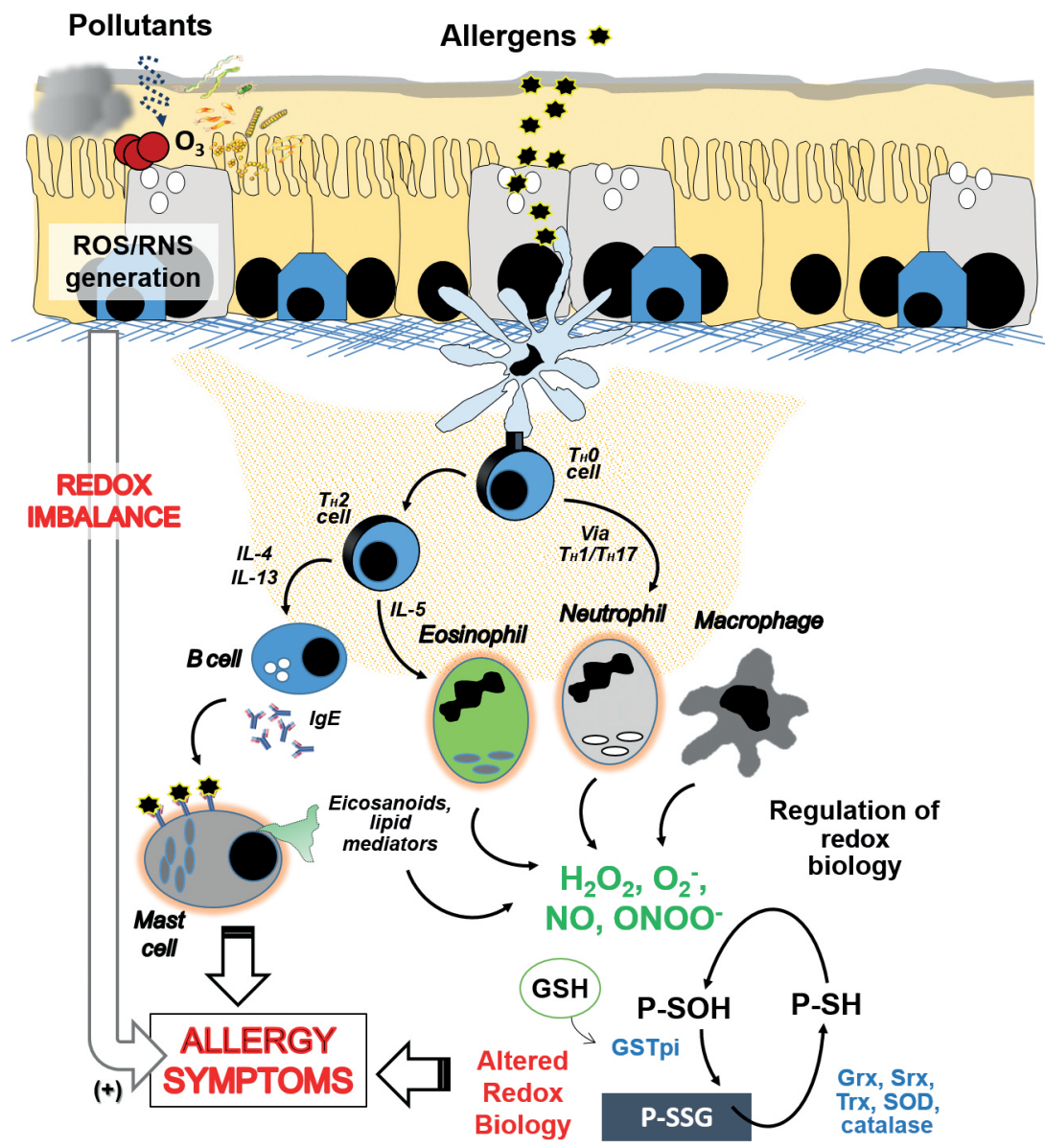

Figure 2. Overview of the molecular mechanisms involved in allergen-triggered immune responses in the context of the lung epithelial redox homeostasis. Reactive oxygen species (ROS) and reactive nitrogen species (RNS) are produced endogenously by eosinophils, neutrophils, and airway macrophages, resulting in S-glutathionylation of reactive cysteine residues within a protein, thus further controlling its activity. Air pollutant interaction with the airway epithelial barrier constitutes an alternate source of oxidants that finally lead to a tissue redox imbalance, enhancing allergic symptoms as stated above. Endogenous and exogenous oxidant species are constantly controlling redox biology in the lung; their levels may act in favor of or against the development of allergic disease. GSH indicates reduced glutathione; Grx, glutaredoxin, GSTpi, glutathione-S-transferase pi; $\mathrm{H}_{2} \mathrm{O}_{2}$, hydrogen peroxide; $\mathrm{NO}$, nitric oxide; $\mathrm{O}_{2}$, superoxide; ONOO-, peroxynitrite; $\mathrm{P}-\mathrm{SH}$, protein thiol; $\mathrm{P}-\mathrm{SOH}$, protein sulfonic acid; P-SSG, protein S-glutathionylation; SOD, superoxide dismutase; Srx, sulfiredoxin; Trx, thioredoxin.

player in orchestrating the allergen immune response, the role of lung "redox biology" in respiratory allergic inflammation, and the effect of air pollutants on the airway epithelium and respiratory allergies.

\section{Airway Epithelium as a Key Player in Orchestrating the Allergic Immune Response}

Besides its role as a selective and highly regulated physical barrier through the establishment of the intercellular apical junctional complexes between neighbouring airway epithelial cells (AECs) [8-11], airway epithelium also acts as a critical orchestrator of the airway immune response through the secretion of a wide repertoire of molecules, including antimicrobial peptides and proteins (eg, lysozyme, defensins, and protease inhibitors), antioxidants (eg, superoxide dismutase and glutathione), chemokines, and cytokines, in response to environmental stimuli [2,12-14].

AECs have been identified as the main source of interleukin 25 (IL-25), IL-33, and thymic stromal lymphopoietin (TSLP), the so-called triad of AEC-derived cytokines. These molecules operate upstream of the canonical $\mathrm{T}_{\mathrm{H}} 2$ cytokines, primarily IL-4, IL-5, and IL-13, which play a pivotal role in allergy (Figure 1) [15]. At the mucosal surface, the triad of AECderived cytokines are important regulators of maintenance of immune homeostasis and induction of both a protective and an inflammatory $\mathrm{T}_{\mathrm{H}}$ 2-type immune response [16-18]. Dysregulation of these cytokines can lead to exacerbated recruitment and activation of specific immune cells, such as dendritic cells (DCs), type-2 innate lymphoid cells (ILC2s), mast cells (MCs), eosinophils, neutrophils, and basophils, and thus promote a long-term $\mathrm{T}_{\mathrm{H}} 2$-type airway hyperresponsiveness spiral. Increased levels of these cytokines have been widely detected in asthma patients [19]. 
Expression and secretion of IL-33 (IL1F11) and IL-25 (IL-17E) are highly regulated in AECs [20-22]. Both cytokines act as amplifiers of the allergic inflammatory immune response $[23,24]$ via the membrane receptors IL-33R and IL17RA/IL-17RB, respectively, which are highly expressed in various immune cells, including ILC2s, MCs, basophils, DCs and macrophages [25-29]. In particular, IL-33 can stimulate MC degranulation [30] and release of IL-8 [31], IL-1B, IL-6, tumor necrosis factor-alpha (TNF- $\alpha$ ), and chemokine (C-C motif) ligand (CCL) 2 [32], which lead to formation of leukotrienes and prostaglandins and can enhance the inflammatory environment in the lungs [33]. In addition, IL-33 also induces expression of IL-9 in freshly isolated basophils and $\mathrm{CD} 4^{+} \mathrm{T}$ cells [34]. IL-25 is able to induce promotion of the $\mathrm{T}_{\mathrm{H}} 2$ lineage via activation of DCs [35] and is involved in the proliferation of a subpopulation of inflammatory ILC2s [36]. Finally, IL-33 and IL-25 also increase basophil activation and migration in allergic asthma patients [37], and high levels of both cytokines have been reported in bronchoalveolar lavage fluid in asthma models [38].

TSLP is highly secreted by AECs in response to allergens, viruses, diesel extract particles, microbes, and helminths via Toll-like receptor (TLR) signalling [39]. Its secretion is also promoted by loss of E-cadherin after injury and exposure to $\mathrm{T}_{\mathrm{H}} 2$ cytokines, such as IL-13 and IL-4 [40,41]. TSLP receptor (the heterodimer IL-7R $\alpha / \gamma \mathrm{c}$-chain) is highly expressed in DCs and ILC2s $[42,43]$. In mice, TSLP is able to induce expression of costimulatory molecules on DCs [44]. In combination with IL-33 and IL-25, TSLP also participates in recruitment and proliferation of ILC2 in the lungs, leading to the release of pro- $\mathrm{T}_{\mathrm{H}} 2$ molecules such as IL-4, IL-5, IL-9, IL-13, and amphiregulin [45], which was recently shown to perpetuate allergic inflammation [46]. TSLP can also modulate several functions of MCs [47], including the release of proinflammatory cytokines such as IL- 6 , TNF- $\alpha$, and IL- $1 \beta$, but not cell degranulation [41]. Finally, TSLP has been associated with susceptibility to multiple allergic diseases by regulating basophil hematopoiesis [48].

AECs also release granulocyte-macrophage colonystimulating factor (GM-CSF), CCL20 and CCL2 [49,50], IL-1 $\alpha$, and IL-4 or IL-13 [51] in response to house dust mite allergens (mite extract and Der $\mathrm{p} 1$ ). These cytokines can induce chemotaxis of MCs and DCs in the epithelium, activation, and migration of DCs to lymph nodes, and polarization of $\mathrm{T}_{\mathrm{H}} 2$ cells [52]. Human and mice bronchial epithelial cells can also produce IL-1 $\alpha$ in response to allergen exposure and have an autocrine effect that potentiates the secretion of the aforementioned cytokines [53]. Eotaxins 1, 2, and 3 delivered by AECs are also able to induce activation of eosinophils and $\mathrm{T}_{\mathrm{H}} 2$ in asthma [54]. In addition, allergen-exposed AECs secrete other alarmins, such as adenosine triphosphate, uric acid and amphoterin (HM-GB1) [55], which are generally released in stress and cell death responses. Increased levels of these molecules have also been reported in patients with asthma [56]. In conclusion, the secretory role of the airway epithelium in orchestrating innate and adaptive immune responses suggests that impaired epithelial barrier function may trigger uncontrolled and deleterious inflammatory processes, such as those observed in allergic reactions.
Aberrant immunochemical actions of the airway epithelium are ultimately determined by the maintenance of the structural integrity of the barrier. Thus, the barrier may be potentially altered by a primary cell-cell junction disruption or alternatively as a consequence of an epithelial remodeling process or epithelial-mesenchymal transition process, both of which involve cell-cell contact disassembly and an increase in the expression of mesenchymal-associated proteins such as $\alpha$-smooth muscle actin, vimentin, and/ or fibronectin [57-59]. The immediate effect of epithelialmesenchymal transition on barrier function is easier access by inhaled antigens across a more permeable epithelial barrier, thus enabling their interaction with local immune cells. A repetitive injury resulting from chronic exposure to allergens may lead to persistent activation of airway repair processes or, in the worst case scenario, altered migration of progenitor cells and abnormal epithelial dedifferentiation, thus further contributing to unbalance the polarized secretion of the proinflammatory epithelium-derived molecules. Airway remodeling-derived inflammation in response to allergens has been widely associated with chronic respiratory diseases such as asthma $[60,61]$ and has been shown to be even more persistent by means of a prolonged allergen challenge in mice [62-64]. Sustained allergen exposure also promotes the persistence of mucous cell hyperplasia in the murine airway wall [65], as well as smooth muscle remodeling in an experimental model of asthma [66].

Various features of a dysfunctional innate immune function of AECs appear to persist in cultures of cells from asthmatic patients, indicating underlying genetic and epigenetic mechanisms [67]. Polymorphisms in IL-6 [68], IL-4 [69], high-affinity IgE receptor [70], IL-4R [71], disintegrin and metalloproteinase 33 [72], and IL-13 [73] have been associated with epithelial dismantling and malfunctioning, especially in the context of asthma and chronic obstructive pulmonary disease $[74,75]$. In this sense, a high level of IL13 in asthmatic patients has been involved in wall remodeling processes $[76,77]$. Moreover, some genetic variants of TSLP have been linked to asthma or allergic rhinitis [78]. The altered genes that appeared in exposed individuals have been implicated in pulmonary effects driven by environmental agents such as viruses, cigarette smoke, oxidants, and air pollution [79-81], explaining, in part, the higher susceptibility of these patients to the action of airborne insults (see below).

\section{Lung and Redox Biology: Role in Respiratory Allergic Inflammation}

Anatomically, the pulmonary epithelium is one of the cell structures most likely to suffer oxidative damage because of continuous exposure to oxidants present in the air, whether generated as part of normal metabolism or exogenously [1]. Oxidants are classified into reactive oxygen species (ROS) and reactive nitrogen species (RNS), and are widely characterized as highly unstable substances. The most physiologically significant ROS are the superoxide anion radical $\left(\mathrm{O}_{2}^{-}\right)$, hydroxyl radical $(\mathrm{OH})$, nitric oxide $(\mathrm{NO})$, and hydrogen peroxide $\left(\mathrm{H}_{2} \mathrm{O}_{2}\right)$. $\mathrm{NO}$ and $\mathrm{H}_{2} \mathrm{O}_{2}$ can react immediately to form 
a highly reactive RNS form of peroxynitrite $\left(\mathrm{ONOO}^{-}\right)$[82]. All these molecules play a relevant role in many cellular processes, such as proliferation, survival, airway remodelling, mucus secretion, and apoptosis and are also critical in the development of airway inflammatory processes [83].

Since all aerobic living forms suffer oxidative damage, the lungs present several antioxidant systems to maintain redox homeostasis. Under normal physiologic conditions, the balance between generation and elimination of ROS/RNS maintains the functional integrity of cell structures and the redox state of signalling proteins. However, prolonged exposure to oxidants can cause dysregulation of redox homeostasis, leading to "oxidative stress", which can in turn lead to cell death and has been proposed as the origin of a variety of airway diseases, such as allergic asthma (Figure 2) [84].

Endogenous oxidants are generated not only by mitochondrial respiration, but also by inflammationactivated cells such as eosinophils, neutrophils, monocytes, macrophages, and tissue-resident cells including endothelial, alveolar, and bronchial epithelial cells. As for the role of mitochondria in inflammation, oxidative stress may cause release to the cytosol of compounds such as damage-associated molecular pattern molecules, adenosine triphosphate, cardiolipins, and mitochondrial DNA, subsequently activating immune signalling cascades via intracellular activation of TLR agonists [85]. Mitochondrial dynamics are directly altered by the presence of airborne particles and protease allergens, leading to changes in membrane potential and proteosomal activity that ultimately leads to proapoptotic events [86,87]. However, the most important source of endogenous oxidants comes from the activation of inflammatory, immune, and structural cells by environmental components (including inhaled allergens), which in turn regulate the expression of specific genes for proinflammatory mediators and antioxidant protective enzymes via activation of redox-sensitive transcription factors such as activator protein-1 (AP-1) and $\mathrm{NF}-\kappa \mathrm{B}$. In addition, inflammatory cells present a variety of oxidant-generating enzymatic systems that amplify the inflammatory response and oxidative stress initiated by exogenous insults, thus contributing to lung damage. Neutrophils, macrophages, and eosinophils produce $\mathrm{O}_{2}^{-}, \mathrm{NO}$, $\mathrm{NO}_{2}$, and $\mathrm{H}_{2} \mathrm{O}_{2}$ by NADPH oxidase (gp91 ${ }^{\text {phox }}-\mathrm{NOX} 2$ ), eosinophil peroxidase (EPO), myeloperoxidase (MPO), and inducible NO synthase (iNOS) [88]. In AECs, NADPH oxidase dual oxidase 1 (DUOX1) catalyzes the generation of ROS and regulates IL-33 secretion and the subsequent $\mathrm{T}_{\mathrm{H}} 2$-immune response to allergen challenge [89].

Besides having a direct deleterious effect on most of the cellular components, leading to lipid peroxidation of membrane phospholipid, depletion of intracellular tripeptide glutathione ( $\gamma$-glutamyl-cysteinyl-glycine [GSH]), DNA damage, and amino acid modification in cellular proteins [90], ROS/RNS also have a critical role in the activation of redox/signalling pathways and transcription factors (see above). Modifications to proteins by physiological oxidants mainly involve reversible oxidation of cysteine residues, which act as cell redox sensors that regulate homeostasis and various biological processes, among them cell proliferation, migration, differentiation, and signalling, as well as gene transcription [5]. In contrast, protein modifications by exogenous oxidants are often associated with the pathogenesis of many human diseases, including asthma, heart disease, neurodegenerative disease, and cancer.

GSH, which contains a sulfhydryl group, is a critical antioxidant in the lung, in particular in the protection of airway epithelium against damage induced by oxidants and inflammation. GSH is the predominant antioxidant in airway cells, ranging from 1 to $11 \mathrm{mM}$ depending on the subcellular compartment, and its concentration in the epithelial lining fluid (ELF) that bathes the entire surface of the lung, is over 100-fold higher than in plasma [91-93]. GSH is a key player in the maintenance of redox homeostasis in the lung, which is mainly defined by the ratio of the concentration of its reduced form to its disulphide form, GSH/GSSG [94]. Under normal conditions, the oxidized form represents less than $1 \%$ of the total GSH pool; however, alterations of the GSH/GSSG ratio in ELF have been described in patients with asthma and other inflammatory disorders such as cystic fibrosis. In this sense, depletion of GSH from the ELF activates inflammatory routes involving $\mathrm{NF} \kappa \mathrm{B}$ activation, thus playing a key role in the expression of proinflammatory genes and cytokine release [95]. In animal models, exposure to toxins, viruses, or allergens such as OVA decreased the total thiol content in bronchoalveolar lavage fluid, thus inducing epithelial apoptosis, cytokine release, and eosinophil influx. However, a higher GSSG content was observed, together with impaired activity of various enzymatic antioxidants such as superoxide dismutase (SOD), catalase, and thioredoxin [96,97]. Lower antioxidant activities, including those associated with GSH synthesis, have also been described in ELF and in cells of asthmatic patients. On the other hand, nuclear factor (erythroid-derived 2)-like 2 is a transcription factor that regulates the expression of phase II and antioxidant enzyme genes, for example, catalase, SOD, glutathione-S-transferase (GST), glutathione peroxidase (GPx), and glutathione synthetase, and is considered a feedback loop that is originally affected by dramatic changes in the GSH/GSSG ratio [1,97]. In this sense, GSTP1- and SOD-specific loci have been strongly associated with asthma and deficiencies in oxidant defenses, although their role remains unclear [98]. As for the protective role of GSH, it is noteworthy that GSH can also be reversibly incorporated into cysteine residues of proteins, through an enzymatic process called S-glutathionylation [99]. This process, which is catalyzed mainly by GSTs, protects oxidanttarget proteins from being irreversibly oxidized, thereby avoiding their aberrant activation or loss of functionality through proteasome degradation [100]. This post-translational modification can alter the activity and function of specific transcription factors involved in inflammatory processes, such as the p65 and p50 subunits of NFkB, thus inhibiting their binding to DNA $[101,102]$ and avoiding the expression of numerous proinflammatory genes. The regulatory inhibitory kappaB kinase beta may also undergo S-glutathionylation, thus allowing the inhibition of $\mathrm{NF} \kappa \mathrm{B}$ transactivation [103]. The expression of other inflammatory genes, such as c-Jun (AP-1), has also been reported to undergo S-glutathionylation [104]. Finally, the rate of S-glutathionylation is markedly lower in patients with asthma [105], thus reinforcing the hypothesis that associates the redox imbalance with the development of 
the pathological features of severe allergic asthma, including airway inflammation and epithelial barrier impairment.

\section{Effect of Air Pollutants on the Airway Epithelium and Respiratory Allergies}

Its anatomical and functional features make the lung the organ with the largest surface exposed to a wide range of air pollutants from natural sources or man-made activities, which have a harmful impact on human health and also on animals and plants. Air pollutants include volatile organic compounds, particulate matter (PM), gases, and metals [106], with carbon monoxide $(\mathrm{CO})$, hydrocarbons, nitrogen dioxide $\left(\mathrm{NO}_{2}\right), \mathrm{PM},\left(\mathrm{SO}_{2}\right)$, and ozone $\left(\mathrm{O}_{3}\right)$ being the most common and abundant. Whilst $\mathrm{O}_{3}$ is formed in the earth's atmosphere by UV light reactions, $\mathrm{CO}, \mathrm{NO}_{2}$, and $\mathrm{PM}$ are generated from fossil fuel burning from motor vehicles, factories, gas heaters, cookers, and cigarette smoke, all of which are concentrated in urban areas. For example, in major cities, up to $90 \%$ of airborne PM consists of diesel exhaust particles, which are high-molecular-weight carbon-based entities $(\sim 100 \mathrm{~nm})$ that can promote allergic airway inflammation and hyperresponsiveness [107-109].

Air pollutants can facilitate sensitization to aeroallergens by a direct effect on airway epithelium and largely contribute to respiratory allergic symptoms and to the pathogenesis of other chronic airway diseases, in particular chronic obstructive pulmonary disease $[110,111]$. Air pollutants act by increasing airway epithelial barrier permeability, inhibiting mucociliary clearance, and inducing AECs to secrete an array of inflammatory mediators such as chemokines, cytokines, eicosanoids, and adhesion molecules that recruit and activate DCs, ILC2s, and basophils, thus contributing to $\mathrm{T}_{\mathrm{H}}$ 2-type immunity. $\mathrm{O}_{3}$ increases the release of IL- 8 , GM-CSF, TNF- $\alpha$, and SICAM-1 on cultured human bronchial epithelial cells [112], while $\mathrm{NO}_{2}$ enhances the secretion of leukotriene $\mathrm{C} 4, \mathrm{CXCL8}$, GM-CSF, and TNF- $\alpha[113,114]$. Moreover, diesel exhaust particles upregulate the mRNA levels of TSLP [115], which can promote maturation of myeloid DCs that support $\mathrm{T}_{\mathrm{H}} 2$-type polarization [116]. Furthermore, numerous studies have shown that smokers exhibit impaired mucociliary clearance [117-120] because of the inhibitory effect of cigarette smoke compounds on the expression of genes involved in ciliogenesis [121]. In turn, an increase in barrier permeability may facilitate the access of aeroallergens to the submucosa and their interaction with resident DCs and ILC2s, as well as with recruited MCs, eosinophils, lymphocytes, and neutrophils [122].

The deleterious effect of air pollutants on airway epithelium has been attributed to oxidative stress [123]. Air pollutants can also generate ROS, which activates NF- $\kappa \mathrm{B}$ signalling in the airway epithelium, leading to the secretion of the epithelial cytokines IL-1, IL-25, IL-33, GM-CSF, and TSLP, as well as other mediators. Subsequently a variety of cellular events are promoted and result in allergic sensitization to inhaled allergens $[124,125] . \mathrm{O}_{3}[126], \mathrm{NO}_{2}$ [127], and cigarette smoke [128,129] induce epithelial cells to release ROS and RNS.

Another mechanism by which air pollutants contribute to respiratory allergies is by interacting with allergens, thus acting as carriers and adjuvants that modify the features of allergens, which in turn enhance the immune response to them. It has been shown that PM and diesel exhaust particles can carry allergens from pollen, cat, dog, and house dust mite [130]. Moreover, it has been reported that air pollution increases the allergenic potency of pollen [131-133]. In their model based on guinea pigs sensitized to Zinnia pollen, Chelregani et al [134] observed that pollen collected from polluted urban areas not only induced higher levels of serum IgE, but also increased eosinophil counts compared with nonpolluted pollen. Finally, growing evidence indicates that air pollutants can increase the production of allergens and proinflammatory mediators in pollens as a result of the plant adaptive response to environmental stress $[131,135]$. In addition, it has been shown that pollens are a source of oxidants [136]. Once pollen NADPH oxidases reach the airway epithelium, levels of ROS and GSSG in ELF increase. These NADPH oxidases, which originally participate in pollen germination and pollen tube formation, could contribute to the allergic airway inflammation induced by the allergen.

\section{Funding}

This study was supported by grant SAF2014-53209-R from the Ministerio de Economía y Competitividad and RIRAAF Network RD12/0013/0015 and ARADyAL Network RD16/0006/0014 from the ISCIII. JCL-R. is supported by a FPU fellowship from the Ministerio de Educación, Cultura y Deporte (Spain). SB is a fellow of the Juan de la Cierva program of the Ministerio de Economía y Competitividad (Spain).

\section{Conflicts of Interest}

The authors declare that they have no conflicts of interest.

\section{References}

1. Biswas SK, Rahman I. Environmental toxicity, redox signaling and lung inflammation: the role of glutathione. Mol Aspects Med. 2009;30(1-2):60-76.

2. Lambrecht $\mathrm{BN}$, Hammad $\mathrm{H}$. Allergens and the airway epithelium response: Gateway to allergic sensitization. J Allergy Clin Immunol. 2014;134(3):499-507.

3. von Mutius E. Gene-environment interactions in asthma. J Allergy Clin Immunol. 2009 Jan;123(1):3.

4. Gandhi VD, Vliagoftis H. Airway Epithelium Interactions with Aeroallergens: Role of Secreted Cytokines and Chemokines in Innate Immunity. Front Immunol. 2015;6(April):1-13.

5. Janssen-Heininger YMW, Mossman BT, Heintz NH, Forman HJ, Kalyanaraman B, Finkel T, et al. Redox-based regulation of signal transduction: principles, pitfalls, and promises. Free Radic Biol Med. 2008 Jul;45(1):1-17.

6. Kinnula VL, Crapo JD, Raivio KO. Generation and disposal of reactive oxygen metabolites in the lung. Lab Invest. 1995 Jul;:73(1):3-19.

7. Finkel T. Signal transduction by reactive oxygen species. J Cell Biol. 2011 Jul; 194(1):7-15.

8. Georas SN, Rezaee F. Epithelial barrier function: at the front line of asthma immunology and allergic airway inflammation. 
Vol. 134, The Journal of allergy and clinical immunology. 2014. p. 509-20.

9. Davies JA, Garrod DR. Molecular aspects of the epithelial phenotype. Bioessays. 1997 Aug;19(8):699-704.

10. Kojima T, Go M, Takano K, Kurose M, Ohkuni T, Koizumi J, et al. Regulation of tight junctions in upper airway epithelium. Biomed Res Int. 2013: 947072.

11. Ganesan S, Comstock AT, Sajjan US. Barrier function of airway tract epithelium. Tissue barriers. 2013;1(4):e24997.

12. Hallstrand TS, Hackett TL, Altemeier WA, Matute-Bello G, Hansbro PM, Knight DA. Airway epithelial regulation of pulmonary immune homeostasis and inflammation. Clin Immunol. 2014;151(1):1-15.

13. Gohy ST, Hupin C, Pilette C, Ladjemi MZ. Chronic inflammatory airway diseases: the central role of the epithelium revisited. Clin Exp Allergy. 2016.

14. Xue L, Salimi M, Panse I, Mjosberg JM, McKenzie ANJ, Spits $\mathrm{H}$, et al. Prostaglandin D2 activates group 2 innate lymphoid cells through chemoattractant receptor-homologous molecule expressed on TH2 cells. J Allergy Clin Immunol. 2014 Apr;133(4):1184-94.

15. Hammad H, Lambrecht BN. Dendritic cells and epithelial cells: linking innate and adaptive immunity in asthma. Nat Rev Immunol. 2008;8(3):193-204.

16. Bartemes KR, Kita H. Dynamic role of epithelium-derived cytokines in asthma. Clin Immunol. 2012 Jun;143(3):222-35.

17. Lloyd CM, Saglani S. Epithelial cytokines and pulmonary allergic inflammation. Curr Opin Immunol. 2015;34:52-8.

18. Pawankar R, Hayashi M, Yamanishi S, Igarashi T. The paradigm of cytokine networks in allergic airway inflammation. Curr Opin Allergy Clin Immunol. 2015;15(1):41-8.

19. Mitchell PD, O'Byrne PM. Epithelial-Derived Cytokines in Asthma. Chest. 2017;151(6):1338-44.

20. Carriere V, Roussel L, Ortega N, Lacorre D-A, Americh L, Aguilar $\mathrm{L}$, et al. IL-33, the IL-1-like cytokine ligand for ST2 receptor, is a chromatin-associated nuclear factor in vivo. Proc Natl Acad Sci U S A. 2007 Jan;104(1):282-7.

21. Luthi AU, Cullen SP, McNeela EA, Duriez PJ, Afonina IS, Sheridan C, et al. Suppression of interleukin-33 bioactivity through proteolysis by apoptotic caspases. Immunity. 2009 Jul;31(1):84-98.

22. Cohen ES, Scott IC, Majithiya JB, Rapley L, Kemp BP, England E, et al. Oxidation of the alarmin IL-33 regulates ST2-dependent inflammation. Nat Commun. 2015 Sep;6:8327.

23. Gour N, Lajoie S. Epithelial Cell Regulation of Allergic Diseases. Curr Allergy Asthma Rep. 2016 Sep;16(9):65.

24. Iwakura $Y$, Ishigame $H$, Saijo $S$, Nakae $S$. Functional specialization of interleukin-17 family members. Immunity. 2011 Feb;34(2):149-62.

25. Yagami A, Orihara K, Morita H, Futamura K, Hashimoto N, Matsumoto $K$, et al. IL-33 mediates inflammatory responses in human lung tissue cells. J Immunol. 2010 Nov; 185(10):5743-50.

26. Besnard A-G, Togbe D, Guillou N, Erard F, Quesniaux V, Ryffel B. IL-33-activated dendritic cells are critical for allergic airway inflammation. Eur J Immunol. 2011 Jun;41(6):1675-86.

27. Kurowska-Stolarska M, Stolarski B, Kewin P, Murphy G, Corrigan CJ, Ying S, et al. IL-33 amplifies the polarization of alternatively activated macrophages that contribute to airway inflammation. J Immunol. 2009 Nov;183(10):6469-77.
28. Toy D, Kugler D, Wolfson M, Vanden Bos T, Gurgel J, Derry J, et al. Cutting edge: interleukin 17 signals through a heteromeric receptor complex. J Immunol. 2006 Jul;177(1):36-9.

29. Chang J, Xia Y-F, Zhang M-Z, Zhang L-M. IL-33 Signaling in Lung Injury. Transl Perioper pain Med. 2016;1(2):24-32.

30. Andrade M V, Iwaki S, Ropert C, Gazzinelli RT, Cunha-Melo $J R$, Beaven MA. Amplification of cytokine production through synergistic activation of NFAT and AP-1 following stimulation of mast cells with antigen and IL-33. Eur J Immunol. 2011 Mar;41(3):760-72.

31. likura M, Suto H, Kajiwara N, Oboki K, Ohno T, Okayama Y, et al. IL-33 can promote survival, adhesion and cytokine production in human mast cells. Lab Invest. 2007 Oct;87(10):971-8.

32. Sabatino G, Nicoletti $M$, Neri G, Saggini $A$, Rosati $M$, Conti F, et al. Impact of IL -9 and IL-33 in mast cells. J Biol Regul Homeost Agents. 2012;26(4):577-86.

33. Enoksson M, Lyberg K, Moller-Westerberg C, Fallon PG, Nilsson $\mathrm{G}$, Lunderius-Andersson C. Mast cells as sensors of cell injury through IL-33 recognition. J Immunol. 2011 Feb; 186(4):25238.

34. Blom L, Poulsen BC, Jensen BM, Hansen A, Poulsen LK. IL-33 induces IL-9 production in human CD4+ T cells and basophils. PLoS One. 2011;6(7):e21695.

35. Hongjia L, Caiqing Z, Degan L, Fen L, Chao W, Jinxiang W, et al. IL-25 promotes Th2 immunity responses in airway inflammation of asthmatic mice via activation of dendritic cells. Inflammation. 2014 Aug;37(4):1070-7.

36. Huang $Y$, Paul WE. Inflammatory group 2 innate lymphoid cells. Int Immunol. 2015;33(12):dxv044.

37. Salter BM, Oliveria JP, Nusca G, Smith SG, Tworek D, Mitchell PD, et al. IL-25 and IL-33 induce Type 2 inflammation in basophils from subjects with allergic asthma. Respir Res. 2016 Jan; 17:5.

38. Beale J, Jayaraman A, Jackson DJ, Macintyre JDR, Edwards MR, Walton RP, et al. Rhinovirus-induced IL-25 in asthma exacerbation drives type 2 immunity and allergic pulmonary inflammation. Sci Transl Med. 2014 Oct;6(256):256ra134.

39. Mitchell PD, O'Byrne PM. Biologics and the lung: TSLP and other epithelial cell-derived cytokines in asthma. Pharmacol Ther. 2017;169:104-12.

40. Kato A, Favoreto SJ, Avila PC, Schleimer RP. TLR3- and Th2 cytokine-dependent production of thymic stromal lymphopoietin in human airway epithelial cells. J Immunol. 2007 Jul; 179(2):1080-7.

41. Allakhverdi Z, Comeau MR, Jessup HK, Yoon B-RP, Brewer A, Chartier $S$, et al. Thymic stromal lymphopoietin is released by human epithelial cells in response to microbes, trauma, or inflammation and potently activates mast cells. J Exp Med. 2007 Feb;204(2):253-8.

42. Isaksen DE, Baumann $H$, Trobridge PA, Farr AG, Levin SD, Ziegler SF. Requirement for stat5 in thymic stromal lymphopoietin-mediated signal transduction. J Immunol. 1999 Dec;163(11):5971-7.

43. Park LS, Martin U, Garka K, Gliniak B, Di Santo JP, Muller W, et al. Cloning of the murine thymic stromal lymphopoietin (TSLP) receptor: Formation of a functional heteromeric complex requires interleukin 7 receptor. J Exp Med. 2000 Sep;192(5):659-70.

44. Pan G, Liang Y, Lu L, Chen X, Wang M, Wang L, et al. Blockage of thymic stromal lymphopoietin signaling improves acute 
lung injury in mice by regulating pulmonary dendritic cells. Int J Clin Exp Pathol. 2015;8(9):10698-706.

45. Halim TYF. Group 2 innate lymphoid cells in disease. Int Immunol. 2016 Jan;28(1):13-22.

46. Karta MR, Broide DH, Doherty TA. Insights into Group 2 Innate Lymphoid Cells in Human Airway Disease. Curr Allergy Asthma Rep. 2016;16(1):1-11.

47. Moon TC, St Laurent CD, Morris KE, Marcet C, Yoshimura T, Sekar Y, et al. Advances in mast cell biology: new understanding of heterogeneity and function. Mucosal Immunol. 2010 Mar;3(2):111-28.

48. Siracusa MC, Saenz SA, Hill DA, Kim BS, Headley MB, Doering TA, et al. TSLP promotes interleukin-3-independent basophil haematopoiesis and type 2 inflammation. Nature. 2011 Aug;477(7363):229-33.

49. Reibman J, Hsu Y, Chen LC, Bleck B, Gordon T. Airway epithelial cells release MIP-3alpha/CCL20 in response to cytokines and ambient particulate matter. Am J Respir Cell Mol Biol. 2003;28(22):648-54.

50. Pichavant M, Charbonnier A-S, Taront S, Brichet A, Wallaert $B$, Pestel J, et al. Asthmatic bronchial epithelium activated by the proteolytic allergen Der p 1 increases selective dendritic cell recruitment. J Allergy Clin Immunol. 2005 Apr;115(4):771-8.

51. Gour N, Wills-Karp M. IL-4 and IL-13 signaling in allergic airway disease. Cytokine. 2015.

52. Ito T, Wang Y-H, Duramad O, Hori T, Delespesse GJ, Watanabe $\mathrm{N}$, et al. TSLP-activated dendritic cells induce an inflammatory T helper type 2 cell response through 0X40 ligand. J Exp Med. 2005 Nov;202(9):1213-23.

53. Willart MAM, Deswarte $K$, Pouliot P, Braun $H$, Beyaert $R$, Lambrecht $B N$, et al. Interleukin-1alpha controls allergic sensitization to inhaled house dust mite via the epithelial release of GM-CSF and IL-33. J Exp Med. 2012 Jul;209(8):1505-17

54. Coleman JM, Naik C, Holguin F, Ray A, Ray P, Trudeau JB, et al. Epithelial eotaxin-2 and eotaxin-3 expression: relation to asthma severity, luminal eosinophilia and age at onset. Thorax. 2012 Dec;67(12):1061-6.

55. Kono H, Rock KL. How dying cells alert the immune system to danger. Nat Rev Immunol. 2008 Apr;8(4):279-89.

56. Willart MAM, Lambrecht BN. The danger within: endogenous danger signals, atopy and asthma. Clin Exp Allergy. 2009 Jan;39(1):12-9.

57. Pain M, Bermudez $\mathrm{O}$, Lacoste $\mathrm{P}$, Royer P-J, Botturi $\mathrm{K}$, Tissot $\mathrm{A}$, et al. Tissue remodelling in chronic bronchial diseases: from the epithelial to mesenchymal phenotype. Eur Respir Rev. 2014 Mar;23(131):118-30.

58. Ozdamar B, Bose R, Barrios-Rodiles M, Wang H-R, Zhang Y, Wrana JL. Regulation of the polarity protein Par6 by TGFbeta receptors controls epithelial cell plasticity. Science. 2005 Mar;307(5715):1603-9.

59. Ikenouchi J, Matsuda M, Furuse M, Tsukita S. Regulation of tight junctions during the epithelium-mesenchyme transition: direct repression of the gene expression of claudins/occludin by Snail. J Cell Sci. 2003 May;116(Pt 10):1959-67.

60. Fehrenbach $H$, Wagner $C$, Wegmann M. Airway remodeling in asthma: what really matters. Cell Tissue Res. 2017 Mar;367(3):551-69.
61. Hogg J. Peripheral lung remodelling in asthma and chronic obstructive pulmonary disease. Vol. 24, The European respiratory journal. England; 2004. p. 893-4.

62. McMillan SJ, Lloyd CM. Prolonged allergen challenge in mice leads to persistent airway remodelling. Clin Exp Allergy. 2004 Mar;34(3):497-507.

63. Johnson JR, Roos A, Berg T, Nord M, Fuxe J. Chronic respiratory aeroallergen exposure in mice induces epithelialmesenchymal transition in the large airways. PLoS One. 2011 Jan;6(1):e16175.

64. Masuda T, Tanaka H, Komai M, Nagao K, Ishizaki M, Kajiwara $D$, et al. Mast cells play a partial role in allergen-induced subepithelial fibrosis in a murine model of allergic asthma. Clin Exp Allergy. 2003 May;33(5):705-13.

65. Kumar RK, Herbert C, Foster PS. Expression of growth factors by airway epithelial cells in a model of chronic asthma: regulation and relationship to subepithelial fibrosis. Clin Exp Allergy. 2004 Apr;34(4):567-75.

66. Ramos-Barbon D, Presley JF, Hamid QA, Fixman ED, Martin $J G$. Antigen-specific CD4+ T cells drive airway smooth muscle remodeling in experimental asthma. J Clin Invest. 2005 Jun;115(6):1580-9.

67. Hiemstra PS, McCray PBJ, Bals R. The innate immune function of airway epithelial cells in inflammatory lung disease. Eur Respir J. 2015 Apr;45(4):1150-62.

68. Babusikova E, Jurecekova J, Jesenak M, Evinova A. Association of Gene Polymorphisms in Interleukin 6 in Infantile Bronchial Asthma. Arch Bronconeumol. 2017 Jul;53(7):381-6.

69. Micheal S, Minhas K, Ishaque M,Ahmed F, Ahmed A. IL-4 gene polymorphisms and their association with atopic asthma and allergic rhinitis in Pakistani patients. J Investig Allergol Clin Immunol. 2013;23(2):107-11.

70. Hizawa N, Yamaguchi E, Jinushi E, Konno S, Kawakami Y, Nishimura M. Increased total serum IgE levels in patients with asthma and promoter polymorphisms at CTLA4 and FCER1B. J Allergy Clin Immunol. 2001 Jul; 108(1):74-9.

71. Slager RE, Otulana BA, Hawkins GA, Yen YP, Peters SP, Wenzel $S E$, et al. IL-4 receptor polymorphisms predict reduction in asthma exacerbations during response to an anti-IL-4 receptor alpha antagonist. J Allergy Clin Immunol. 2012 Aug;130(2):516-22.

72. Shah S, Rashid A, Shah ZA, Jan RA, Khan UH, Bhat IA, et al. A disintegrin and metalloprotease 33 polymorphism association with COPD in long-term tobacco smokers of the ethnic Kashmiri population of India. Lung India. 2015;32(3):220-4.

73. Xu Y, Li J, Ding Z, Li J, Li B, Yu Z, et al. Association between IL$13+1923$ C/T polymorphism and asthma risk: a meta-analysis based on 26 case-control studies. Biosci Rep. 2017;37(1).

74. Reddy AJ, Kleeberger SR. Genetic polymorphisms associated with acute lung injury. Pharmacogenomics. 2009;10(9):152739.

75. Bierbaum S, Heinzmann A. The genetics of bronchial asthma in children. Respir Med. 2007;101(7):1369-75.

76. Yang G, Volk A, Petley T, Emmell E, Giles-Komar J, Shang $X$, et al. Anti-IL-13 monoclonal antibody inhibits airway hyperresponsiveness, inflammation and airway remodeling. Cytokine. 2004; 28(6):224-32.

77. Kumar RK, Herbert C, Yang M, Koskinen AML, McKenzie ANJ, Foster PS. Role of interleukin-13 in eosinophil accumulation 
and airway remodelling in a mouse model of chronic asthma. Clin Exp Allergy. 2002 Jul;32(7):1104-11.

78. Cianferoni A, Spergel J. The importance of TSLP in allergic disease and its role as a potential therapeutic target. Expert Rev Clin Immunol. 2014 Nov;10(11):1463-74.

79. Klingbeil EC, Hew KM, Nygaard UC, Nadeau KC. Polycyclic aromatic hydrocarbons, tobacco smoke, and epigenetic remodeling in asthma. Immunol Res. 2014 May;58(2-3):36973.

80. Ho S-M. Environmental epigenetics of asthma: an update. J Allergy Clin Immunol. 2010 Sep;126(3):453-65.

81. Molfino NA, Coyle AJ. Gene-environment interactions in chronic obstructive pulmonary disease. Int J Chron Obstruct Pulmon Dis. 2008;3(3):491-7.

82. Comhair SAA, Erzurum SC. Redox control of asthma: molecular mechanisms and therapeutic opportunities. Antioxid Redox Signal. 2010 Jan;12(1):93-124.

83. Ckless K, Hodgkins SR, Ather JL, Martin R, Poynter ME. Epithelial, dendritic, and CD4(+) T cell regulation of and by reactive oxygen and nitrogen species in allergic sensitization. Biochim Biophys Acta. 2011 Nov; 1810(11):1025-34.

84. Haddad JJ. Oxygen-sensing mechanisms and the regulation of redox-responsive transcription factors in development and pathophysiology. Respir Res. 2002;3:26.

85. Iyer D, Mishra N, Agrawal A. Mitochondrial Function in Allergic Disease. Curr Allergy Asthma Rep. 2017 May;17(5):29.

86. Gosens I, Post JA, de la Fonteyne LJ, Jansen EHJM, Geus JW, Cassee FR, et al. Impact of agglomeration state of nano- and submicron sized gold particles on pulmonary inflammation. Part Fibre Toxicol. 2010 Dec; 7(1):37.

87. Kipen HM, Gandhi S, Rich DQ, Ohman-Strickland P, Laumbach $\mathrm{R}$, Fan Z-H, et al. Acute decreases in proteasome pathway activity after inhalation of fresh diesel exhaust or secondary organic aerosol. Environ Health Perspect. 2011 May:119(5):658-63.

88. Erzurum SC. New Insights in Oxidant Biology in Asthma. Ann Am Thorac Soc. 2016 Mar;13 Suppl 1:S35-9.

89. Hristova $M$, Habibovic $A$, Veith $C$, Janssen-Heininger YMW, Dixon $A E$, Geiszt $M$, et al. Airway epithelial dual oxidase 1 mediates allergen-induced IL-33 secretion and activation of type 2 immune responses. J Allergy Clin Immunol. 2016 May;137(5):1545-56.e11.

90. Hoffman S, Nolin J, McMillan D, Wouters E, JanssenHeininger $Y$, Reynaert $N$. Thiol redox chemistry: role of protein cysteine oxidation and altered redox homeostasis in allergic inflammation and asthma. J Cell Biochem. 2015 Jun;116(6):884-92.

91. Moss M, Guidot DM, Wong-Lambertina $M$, Ten Hoor $T$, Perez RL, Brown LA. The effects of chronic alcohol abuse on pulmonary glutathione homeostasis. Am J Respir Crit Care Med. 2000 Feb;161(2.1):414-9.

92. Mudway IS, Stenfors N, Blomberg A, Helleday R, Dunster C, Marklund $S L$, et al. Differences in basal airway antioxidant concentrations are not predictive of individual responsiveness to ozone: a comparison of healthy and mild asthmatic subjects. Free Radic Biol Med. 2001 Oct;31(8):962-74.

93. Nadeem A, Chhabra SK, Masood A, Raj HG. Increased oxidative stress and altered levels of antioxidants in asthma. J Allergy Clin Immunol. 2003 Jan;111(1):72-8.
94. Fitzpatrick AM, Jones DP, Brown LAS. Glutathione redox control of asthma: from molecular mechanisms to therapeutic opportunities. Antioxid Redox Signal. 2012 Jul;17(2):375-408.

95. Yang S-R, Chida AS, Bauter MR, Shafiq N, Seweryniak $\mathrm{K}$, Maggirwar SB, et al. Cigarette smoke induces proinflammatory cytokine release by activation of NF-kappaB and posttranslational modifications of histone deacetylase in macrophages. Am J Physiol Lung Cell Mol Physiol. 2006 Jul;291(1):L46-57.

96. Nadeem A, Masood A, Siddiqui N. Oxidant--antioxidant imbalance in asthma: scientific evidence, epidemiological data and possible therapeutic options. Ther Adv Respir Dis. 2008 Aug;2(4):215-35.

97. Sahiner UM, Birben E, Erzurum S, Sackesen C, Kalayci 0. Oxidative stress in asthma. World Allergy Organ J. 2011 Oct; $4(10): 151-8$.

98. Schroer KT, Gibson AM, Sivaprasad U, Bass SA, Ericksen $M B$, Wills-Karp $M$, et al. Downregulation of glutathione S-transferase pi in asthma contributes to enhanced oxidative stress. J Allergy Clin Immunol. 2011 Sep;128(3):539-48.

99. Dalle-Donne I, Rossi R, Giustarini D, Colombo R, Milzani A. $S$-glutathionylation in protein redox regulation. Free Radic Biol Med. 2007 Sep;43(6):883-98.

100. Mallis RJ, Hamann MJ, Zhao W, Zhang T, Hendrich S, Thomas JA. Irreversible thiol oxidation in carbonic anhydrase III: protection by S-glutathiolation and detection in aging rats. Biol Chem. 2002;383(3-4):649-62.

101. Qanungo S, Starke DW, Pai H V, Mieyal JJ, Nieminen A-L. Glutathione supplementation potentiates hypoxic apoptosis by S-glutathionylation of p65-NFkappaB. J Biol Chem. 2007 Jun;282(25):18427-36.

102. Pineda-Molina E, Klatt P, Vazquez J, Marina A, Garcia de Lacoba $M$, Perez-Sala $D$, et al. Glutathionylation of the p50 subunit of NF-kappaB: a mechanism for redox-induced inhibition of DNA binding. Biochemistry. 2001 Nov;40(47):14134-42.

103. Reynaert NL, van der Vliet $A$, Guala AS, McGovern T, Hristova M, Pantano C, et al. Dynamic redox control of NF-kappaB through glutaredoxin-regulated S-glutathionylation of inhibitory kappaB kinase beta. Proc Natl Acad Sci U S A. 2006 Aug; 103(35):13086-91.

104. Rahman I, Gilmour PS, Jimenez LA, MacNee W. Oxidative stress and TNF-alpha induce histone acetylation and NFkappaB/AP-1 activation in alveolar epithelial cells: potential mechanism in gene transcription in lung inflammation. Mol Cell Biochem. 2002;234-235(1-2):239-48.

105. Jiang L, Diaz PT, Best TM, Stimpfl JN, He F, Zuo L. Molecular characterization of redox mechanisms in allergic asthma. Ann Allergy Asthma Immunol. 2014 Aug;113(2):137-42.

106. Akimoto H. Global Air Quality and Pollution. Science. 2003;302(5651):1716-9.

107. Yang SN, Hsieh CC, Kuo HF, Lee MS, Huang MY, Kuo CH, et al. The effects of environmental toxins on allergic inflammation. Allergy, Asthma Immunol Res. 2014;6(6):478-84.

108. Levetin E, Van de Water P. Environmental contributions to allergic disease. Curr Allergy Asthma Rep. 2001;1:506-14.

109. Kelly FJ, Fussell JC. Air pollution and airway disease. Clin Exp Allergy. 2011;41(8):1059-71.

110. Provost EB, Chaumont A, Kicinski M, Cox B, Fierens F, Bernard $A$, et al. Serum levels of club cell secretory protein (Clara) and 
short- and long-term exposure to particulate air pollution in adolescents. Environ Int. 2014;68:66-70.

111. Dietert RR, DeWitt JC, Germolec DR, Zelikoff JT. Breaking patterns of environmentally influenced disease for health risk reduction: Immune perspectives. Environ Health Perspect. 2010;118(8):1091-9.

112. Rusznak C, Devalia JLL, Sapsford RJJ, Davies RJJ. Ozoneinduced mediator release from human bronchial epithelial cells $<\mid>$ in vitro $</ l>$ and the influence of nedocromil sodium. Eur Respir J. 1996;9(11):2298-305.

113. Devalia JL, Campbell AM, Sapsford RJ, Rusznak C, Quint D, Godard P, et al. Effect of nitrogen dioxide on synthesis of inflammatory cytokines expressed by human bronchial epithelial cells in vitro. Am J Respir Cell Mol Biol. 1993;9(3):271-8.

114. Devalia JL, Sapsford RJ, Cundell DR, Rusznak C, Campbell AM, Davies RJ. Human bronchial epithelial cell dysfunction following in vitro exposure to nitrogen dioxide. Eur Respir J. 1993;6(9):1308-16.

115. Bleck B, Grunig G, Chiu A, Liu M, Gordon T, Kazeros A, et al. MicroRNA-375 regulation of thymic stromal lymphopoietin by diesel exhaust particles and ambient particulate matter in human bronchial epithelial cells. J Immunol. 2013;190(7):3757-63.

116. Bleck B, Tse DB, Jaspers I, Curotto MA, Lafaille D, Reibman $J$, et al. Diesel exhaust particle-exposed human bronchial epithelial cells induce dendritic cell maturation. J Immunol. 2006;176(12):7431-7.

117. Vastag E, Matthys H, Kohler D, Gronbeck L, Daikeler G. Mucociliary clearance and airways obstruction in smokers, exsmokers and normal subjects who never smoked. Eur J Respir Dis Suppl. 1985; 139:93-100.

118. Goodman RM, Yergin BM, Landa JF, Golivanux MH, Sackner MA. Relationship of smoking history and pulmonary function tests to tracheal mucous velocity in nonsmokers, young smokers, ex-smokers, and patients with chronic bronchitis. Am Rev Respir Dis. 1978 Feb;117(2):205-14.

119. Lourenço R V., Klimek MF, Borowski CJ. Deposition and clearance of 2 micron particles in the tracheobronchial tree of normal subjects--smokers and nonsmokers. J Clin Invest. 1971;50(7):1411-20.

120. Camner P, Philipson K. Tracheobronchial clearance in smokingdiscordant twins. Arch Environ Health. 1972 Jul;25(1):60-3.

121. Brekman A, Walters MS, Tilley AE, Crystal RG. FOXJ1 prevents cilia growth inhibition by cigarette smoke in human airway epithelium in vitro. Am J Respir Cell Mol Biol. 2014;51(5):688700.

122. Lambrecht BN, Hammad $H$. The immunology of the allergy epidemic and the hygiene hypothesis. Nat Immunol. 2017;(18):1076-83.

123. D'Amato G, Holgate ST, Pawankar R, Ledford DK, Cecchi L, AlAhmad $\mathrm{M}$, et al. Meteorological conditions, climate change, new emerging factors, and asthma and related allergic disorders. A statement of the World Allergy Organization. World Allergy Organ J. 2015;8(1):25.
124. Bleck B, Tse DB, Gordon T, Ahsan MR, Reibman J. Diesel exhaust particle-treated human bronchial epithelial cells upregulate Jagged-1 and OX40 ligand in myeloid dendritic cells via thymic stromal lymphopoietin. J Immunol. 2010 Dec;185(11):6636-45.

125. Brandt EB, Myers JMB, Ryan PH, Hershey GKK. Air pollution and allergic diseases. Curr Opin Pediatr. 2015 Dec;27(6):724-35.

126. Song $H$, Tan $W$, Zhang $X$. Ozone induces inflammation in bronchial epithelial cells. J Asthma. 2011 Feb;48(1):79-83.

127. Tunnicliffe WS, Burge PS, Ayres JG. Effect of domestic concentrations of nitrogen dioxide on airway responses to inhaled allergen in asthmatic patients. Lancet (London, England). 1994 Dec;344(8939-8940):1733-6.

128. Ishikawa $S$, Ito $S$. Repeated whole cigarette smoke exposure alters cell differentiation and augments secretion of inflammatory mediators in air-liquid interface threedimensional co-culture model of human bronchial tissue. Toxicol In Vitro. 2017 Feb;38:170-8.

129. Comer DM, Elborn JS, Ennis M. Inflammatory and cytotoxic effects of acrolein, nicotine, acetylaldehyde and cigarette smoke extract on human nasal epithelial cells. BMC Pulm Med. 2014 Mar;14:32.

130. Ormstad H, Johansen B V, Gaarder Pl. Airborne house dust particles and diesel exhaust particles as allergen carriers. Clin Exp Allergy. 1998 Jun;28(6):702-8

131. Senechal H, Visez N, Charpin D, Shahali Y, Peltre G, Biolley $J-P$, et al. A Review of the Effects of Major Atmospheric Pollutants on Pollen Grains, Pollen Content, and Allergenicity. ScientificWorldJournal. 2015;2015:940243.

132. Schiavoni G, D'Amato G, Afferni C. The dangerous liaison between pollens and pollution in respiratory allergy. Ann Allergy Asthma Immunol. 2017 Mar;118(3):269-75.

133. Bartra Tomás J, Mullol J, Del Cuvillo A, Dávila I, Ferrer $M$, Jáuregui I, et al. Air pollution and allergens. J Investig Allergol Clin Immunol. 2007;17(2):3-8.

134. Chehregani A, Maide A, Gholami M, Ali Shariatzadeh M, Nassiri $H$. Increasing allergy potency of Zinnia pollen grains in polluted areas. Ecotoxicol Environ Saf. 2004;58(2):267-72.

136. Boldogh I, Bacsi A, Choudhury BK, Dharajiya N, Alam R, Hazra TK, et al. ROS generated by pollen NADPH oxidase provide a signal that augments antigen-induced allergic airway inflammation. J Clin Invest. 2005 Aug;115(8):2169-7.

- Manuscript received July 26, 2017; accepted for publication September 21, 2017.

\section{E Batanero}

Departamento de Bioquímica y Biología Molecular I

Facultad de Ciencias Químicas

Universidad Complutense, Madrid, Spain

E-mail: ebataner@ucm.es 